Review Article

\title{
Absence of Pathogenicity in Non-Human Primates of Mutations Related to Retinoblastoma in Humans
}

\author{
Héctor N Seuánez ${ }^{1 *}$, Maria C Viana', William C Tavares ${ }^{1,2}$, Vanessa Mendonça' ${ }^{1}$, Ayslan C Brant' ${ }^{1}$ Mariana Boroni ${ }^{3}$ and Evandro Lucena ${ }^{4}$ \\ 'Genetics Program, Instituto Nacional de Câncer, Rua André Cavalcanti, 37, Rio de Janeiro, Brazil \\ ${ }^{2}$ Department of Genetics, Universidade Federal do Rio de Janeiro, Cidade Universitária, Rio de Janeiro, Brazil \\ ${ }^{3}$ Bioinformatics Unit, Instituto Nacional de Câncer, Rua André Cavalcanti, 37, Rio de Janeiro, Brazil \\ ${ }^{4}$ Clinical Research Division, Instituto Nacional de Câncer. Rua André Cavalcanti, 37, Rio de Janeiro, Brazil
}

\begin{abstract}
The tumor suppressor, Human Retinoblastoma Susceptibility Gene (RB1) plays a prominent role in normal development, gene transcription, DNA replication, repair, and mitosis, and its complete biallelic dysfunction in retinoblasts is the main cause of retinoblastoma in humans. Comparisons between the reference, human $R B 1$ coding region with its counterparts in 19 non-human primates showed that several $R B 1$ alterations accompanying retinoblastoma in the human were present in several non-human primates without apparent pathological effects. Comparative analyses of molecular data were most useful for tracing the evolution of $R B 1$, identifying the polarity of mutational events, the physico-chemical effects conferred by amino acid substitutions, and the number of codons under selection. These historic reconstructions indicated that several $R B 1$ mutations found in retinoblastoma in the human were presumably atavistic, accounting for evolutionary regressions. Moreover, some same-sense RB1 mutations, despite specifying for the same amino acids, were probably ancient adaptations that took place in our evolutionary lineage.
\end{abstract}

Keywords: Retinoblastoma; RB1 gene; Mutations; Evolution

\section{Introduction}

Retinoblastoma (RB; OMIM \#180200) is an embryonic malignant tumor and the most common primary ocular tumor in children with an incidence of approximately 1 in 14,000 to 34,000 live births per year, accounting for the second most common tumor of the first year of age. Early diagnosis and treatment have dramatically improved during the last 80 years, with $>90 \%$ of currently diagnosed children being cured of retinoblastoma in most developed countries [1,2]. In this malignancy, either hereditary or sporadic, deleterious alterations resulting in complete biallelic dysfunction of the Retinoblastoma-1 gene $\left(R B 1\right.$; OMIM $\left.{ }^{*} 614041\right)$ are the main cause of tumor development [3]. $R B 1$ is a tumor suppressor gene that exerts a negative regulation of the cell cycle by binding the E2F transcription factor and repressing the transcription of genes required for the $S$ phase [4]. $R B 1$ plays a prominent role in development, gene transcription, DNA replication, DNA repair and mitosis, and is an evolutionary conserved gene across several organismal taxa consequently to its manifold biological

Citation: Seuánez HN, Viana MC, Tavares WC, Mendonça V, Brant AC, Boroni M, et al. Absence of Pathogenicity in Non-Human Primates of Mutations Related to Retinoblastoma in Humans. World J Vet Res. 2021; 1(1): 1002.

Copyright: @ 2021 Héctor N Seuánez

Publisher Name: Medtext Publications LLC

Manuscript compiled: Jun $10^{\text {th }}, 2021$

*Corresponding author: Héctor N. Seuánez, Department of Genetics, Instituto Nacional de Câncer, Rua André Cavalcanti, 37, 20231-050. Rio de Janeiro, R.J., Brazil, Tel: +55 213207 6582; Fax: +55 213207 6553; E-mail: hseuanez@inca.gov.br functions [4]. Its complete biallelic dysfunction may result from nucleotide substitutions, deletions or insertions [6]. Hereditary RB may occur in constitutional carriers of one dysfunctional $R B 1$ allele present in the genome of a progenitor or generated by mutations during gametogenesis. In these predisposed constitutional carriers, in which one dysfunctional $R B 1$ allele is present in all cells, RB will eventually occur when a second, somatic mutation takes place in retinoblasts, transforming the other $R B 1$ allele into a dysfunctional one. Conversely, in the non-hereditary, or sporadic RB, both mutations are somatic (viz, present in retinoblasts), according the two-hit hypothesis postulated by Knudson [7].

\section{The Basic Structure of $R B 1$ and its Translated Protein}

$R B 1$ is located in a region of the long arm of human chromosome 13 (13q14.2) delimited by a pattern of differentially stained regions (bands) along this chromosome arm (Figure 1). RB1 is a long gene, spanning along 180 kilobases and consisting 27 exons (portions of genes whose RNA transcripts survive RNA processing and specify a partial amino acid sequence of complete proteins). These exons are flanked by 27 introns (segments of DNA between exons that are transcribed into nuclear RNA, but are removed in the subsequent processing into messenger RNA). A mature mRNA transcript of approximately 4,700 bases (Genbank NM000321) is normally translated to the Retinoblastoma-associated protein (pRB) encompassing 928 amino acids (Figure 1) $[6,8,9]$. This protein is a member of a small protein family, with two discontinuous regions known as RB_A and RB_B domains containing a cyclin-fold structural motif. These two domains form the $\mathrm{AB}$ pocket that is critical for tumor suppressor activity [10] and are separated by a spacer region of 71 amino acids. The C-terminal RB_C region (or C pocket) is responsible for blocking the G1-S transition of the cell cycle and is required for binding the E2F 


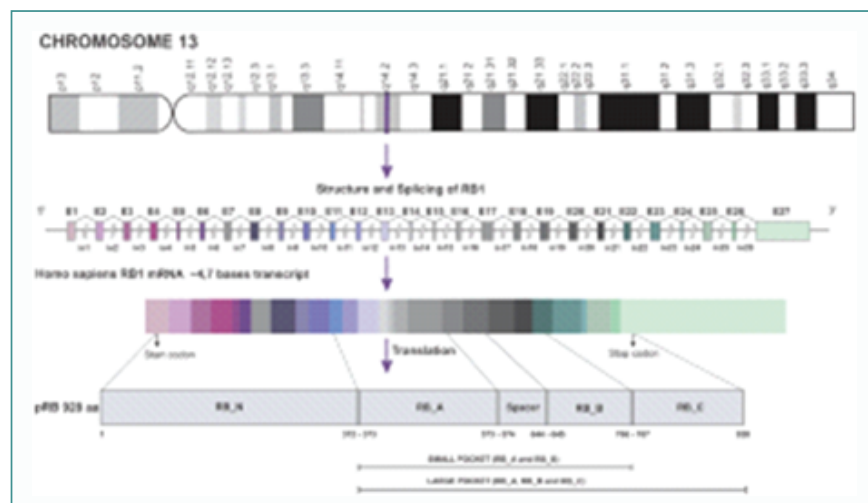

Figure 1: Location of $R B 1$ in chromosome 13, showing exons, introns and splicing; Homo sapiens RB1 mRNA and translation product with 928 residues and functional domains. RB_N = N-terminal region, RB_A = Pocket A, RB_B $=$ Pocket B, RB_C = C-terminal region. Sources: Viana et al. [20] GeneCards (20); UniProt [21]; Pfam 29.0 [22]; Hasan et al. [23]; Rubin et al. [24].

transcription factor and mediating growth arrest $[10,11]$. Altogether, the small pocket and the $\mathrm{C}$ pocket form the so-called large $\mathrm{pRB}$ pocket. Additionally, the N-terminal (RB_N) region contains CDKphosphorylation sites involved in the regulation of $\mathrm{pRB}$ activity.

\section{Different Species Share Similar Genes}

Comparisons between humans and 19 non-human primates using algorithms for DNA sequence alignment showed gene counterparts in these species [12]. These counterparts are "homologous" (rather than "analogous") to our genes with which they share a common evolutionary origin. Homologous genes, however, are similar rather than identical because several mutations occurring along the process of evolutionary diversification put an end to their original ancestral identity. In this scenario, a reconstruction of this process throughout several million years showed that the evolutionary change of genes of high biological significance, like RB1, must have been compatible with conservation of their main properties and functions. This accounted for qualitative and quantitative constraints to evolutionary change for overcoming the pressure that natural selection exerts on organisms. And as a corollary to the postulate of evolutionary conservation we are lead to intuitively envisage that deleterious alterations of the $R B 1$ gene in humans should also be deleterious in related species.

\section{RB1-related Mutations in the Human and 19 Selected Primates}

The online Leiden Open Variations Database v.2.0 Build 34 (RB1LOVD) presently reports 1,794 different $R B 1$ mutational variants found in retinoblastoma [13]. This dataset includes all sequences that differ from the reference mRNA sequence of the RB1 gene (NM000321), classifying them according to their expected impact on DNA, RNA and pRB structure. This dataset indicates that a several $R B 1$ alterations are pathogenic, providing good evidence that the integrity of $R B 1$ is crucial for its normal function. Contrary to our expectations, nine $R B 1$ mutational variants, similar to or identical with those listed in the RB1-LOVD database, were found to be present in several non-human primates (Table 1). Moreover, some RB1 mutational variants were present in a considerable number of species, indicating that their presence was far from casual. We will first review the mutations that produced these variants before we discuss their biological significance with respect to the etiology of retinoblastoma as well as their presumed evolutionary origin. An explanation of the terminology herein used for describing mutations is presented in Figure 2. Six mutations were same-sense (presumably silent), two were missense, and one was nonsense producing a stop codon. Seven of them were found in retinoblastoma in humans and two other were also included in the RB1-LOVD database in view of their likely, though less obvious, RB relation. One missense mutation (c.385C > T;p.His129Tyr)found in bilateral RB in humans was found in nine species of non-human primates while another missense mutation (c.1102G>A;pVal368Ile) was present in the orangutan, a species phylogenetically close to humans. None of these mutations resulting in aminoacid substitutions were reported with abnormal phenotypes in these non-human primates. Moreover, three samesense mutations (c.1215C >T;p.Asn405Asn, c.1860G >A;p.Thr620Thr and c.2517C > T;p.Phe839Phe) were found in a high number of species across a wide taxonomic spectrum against three other same-sense mutations (c.291A>G;p.Glu97Glu, c.1140C>T;p.Asn380Asn and c.2463A>G;p.Thr821Thr) present in a smaller number of species. Here again, there was no report on the presumptive pathogenicity of these mutations in the non-human primates.

\section{What is the Relation Between these Mutations and Retinoblastoma?}

The RB1-LOVD databaselistsall mutations found in retinoblastoma with information on their potential pathogenicity. But association, in fact, refers to the occurrence together in a population, more often than can be readily explained by chance, of two or more traits of which at least one is known to be genetic. This does not imply that correlation, viz. a mutual relationship or connection between two or more traits, might exist. Even if they were someway correlated, any two or more events are not necessarily connected by a cause-effect relation. Within this context, the most reasonable assessment of the pathogenicity of mutations is provided by their presumptive effect on pRB. Certainly, a nonsense mutation like c. 1943C $>$ A;p.Ser648X resulting in a truncated $\mathrm{pRB}$ can be considered as pathogenic and we can therefore assume that it is highly likely to be causative of retinoblastoma (Figure 3). Similarly, algorithms devised for determining protein structure like Deep View - Swiss Pro (https://spdbv.vital-it.ch) are useful tools for visualizing the effects of aminoacid substitutions in modifying the secondary pRB structure and establishing an etiological (cause-effect) relation between mutations and pathogenicity [14]. Several algorithms are presently available for analyzing mutations with respect to their presumed pathogenicity (varsome - The human genomic community https://varsome.com;ClinVar https://www.ncbi.nlm.nih.gov/clinvar) [15].

What can be said about same-sense mutations given that they do

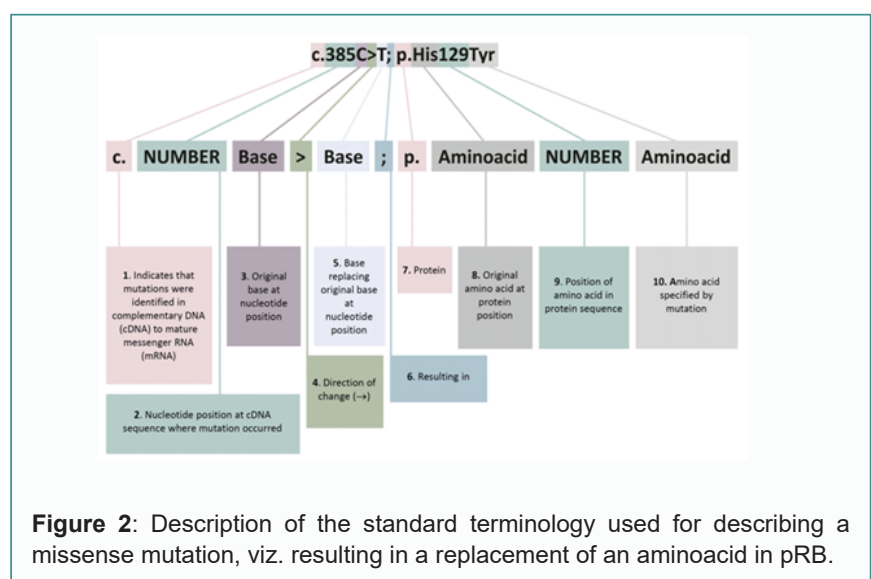


Table 1: cDNA position, expected consequence and protein changes with respect to retinoblastoma data (RB1-LOVD).

\begin{tabular}{|c|c|c|c|c|c|c|c|c|c|}
\hline \multirow{4}{*}{\begin{tabular}{|l} 
TAXA \\
H. sapiens \\
\end{tabular}} & \multicolumn{9}{|c|}{ ALTERATIONS FOUND WITH RETINOBLASTOMA LISTED IN RB1-LOVD AND PRESENT IN OTHER PRIMATES } \\
\hline & c.291A>G & c.385C $>\mathrm{T}$ & c. $1102 \mathrm{G}>\mathrm{A}$ & c. $1140 \mathrm{C}>\mathrm{T}$ & c. $1215 \mathrm{C}>\mathrm{T}$ & c. $1860 \mathrm{G}>\mathrm{A}$ & c. $1943 \mathrm{C}>\mathrm{A}$ & c. $2463 \mathrm{~A}>\mathrm{G}$ & c. $2517 \mathrm{C}>\mathrm{T}$ \\
\hline & Silent & Missense & Missense & Silent & Silent & Silent & Stop codon & Silent & Silent \\
\hline & p.Glu97Glu & p.His129Tyr & p.Val368Ile & p.Asn380Asn & p.Asn405Asn & p.Thr620Thr & p.Ser648X & p.Thr821Thr & p.Phe839Phe \\
\hline Effect & Unilateral RB & Bilateral RB & $\mathrm{RB}$ & Unilateral RB & Unilateral RB & No Cancer & Bilateral RB & Unilateral RB & Other Cancer \\
\hline \multicolumn{10}{|l|}{ P. paniscus } \\
\hline \multicolumn{10}{|l|}{ P. troglodytes } \\
\hline \multicolumn{10}{|l|}{ G. gorilla } \\
\hline P. abelii & & & $\begin{array}{l}\text { c.1102G>A } \\
\text { Missense } \\
\text { p.Val368Ile }\end{array}$ & & & $\begin{array}{l}\text { c. } 1860 \mathrm{G}>\mathrm{A} \\
\text { Silent } \\
\text { p.Thr620Thr }\end{array}$ & & & $\begin{array}{l}\text { c. } 2517 \mathrm{C}>\mathrm{T} \\
\text { Silent } \\
\text { p.Phe839Phe }\end{array}$ \\
\hline N. leucogenys & & & & $(*)$ & & & & & \\
\hline C. sabaeus & & & & & $\begin{array}{l}\text { c.1215C>T } \\
\text { Silent } \\
\text { p.Asn405Asn }\end{array}$ & $\begin{array}{l}\text { c.1860G }>\text { A } \\
\text { Silent } \\
\text { p.Thr620Thr }\end{array}$ & & $\begin{array}{l}\text { c.2463A }>\mathrm{G} \\
\text { Silent } \\
\text { p.Thr821Thr }\end{array}$ & $\begin{array}{l}\text { c. } 2517 \mathrm{C}>\mathrm{T} \\
\text { Silent } \\
\text { p.Phe839Phe }\end{array}$ \\
\hline M. mulatta & & & & & $\begin{array}{l}\text { c. } 1215 \mathrm{C}>\mathrm{T} \\
\text { Silent } \\
\text { p.Asn } 405 \text { Asn }\end{array}$ & $\begin{array}{l}\text { c. } 1860 \mathrm{G}>\mathrm{A} \\
\text { Silent } \\
\text { p.Thr620Thr }\end{array}$ & & & $\begin{array}{l}\text { c.2517C>T } \\
\text { Silent } \\
\text { p.Phe839Phe }\end{array}$ \\
\hline R. roxellana & & & & & $\begin{array}{l}\text { c.1215C>T } \\
\text { Silent } \\
\text { p.Asn } 405 \text { Asn }\end{array}$ & $\begin{array}{l}\text { c. } 1860 \mathrm{G}>\mathrm{A} \\
\text { Silent } \\
\text { p.Thr620Thr }\end{array}$ & & & $\begin{array}{l}\text { c. } 2517 \mathrm{C}>\mathrm{T} \\
\text { Silent } \\
\text { p.Phe839Phe }\end{array}$ \\
\hline C. atys & & & & & $\begin{array}{l}\text { c. } 1215 \mathrm{C}>\mathrm{T} \\
\text { Silent } \\
\text { p.Asn } 405 \text { Asn }\end{array}$ & $\begin{array}{l}\text { c. } 1860 \mathrm{G}>\mathrm{A} \\
\text { Silent } \\
\text { p.Thr620Thr }\end{array}$ & & & $\begin{array}{l}\text { c. } 2517 \mathrm{C}>\mathrm{T} \\
\text { Silent } \\
\text { p.Phe839Phe }\end{array}$ \\
\hline M. leucophaeus & & & & & $\begin{array}{l}\text { c.1215C }>\text { T } \\
\text { Silent } \\
\text { p.Asn405Asn }\end{array}$ & $\begin{array}{l}\text { c.1860G }>\text { A } \\
\text { Silent } \\
\text { p.Thr620Thr }\end{array}$ & & & $\begin{array}{l}\text { c.2517C }>\text { T } \\
\text { Silent } \\
\text { p.Phe839Phe }\end{array}$ \\
\hline B. arachnoides & & $\begin{array}{l}\text { c. } 385 \mathrm{C}>\mathrm{T} \\
\text { Missense } \\
\text { p.His129Phe }\end{array}$ & & & $\begin{array}{l}\text { c.1215C }>\mathrm{T} \\
\text { Silent } \\
\text { p.Asn405Asn }\end{array}$ & $\begin{array}{l}\text { c. } 1860 \mathrm{G}>\mathrm{A} \\
\text { Silent } \\
\text { p.Thr620Thr }\end{array}$ & & & $\begin{array}{l}\text { c. } 2517 \mathrm{C}>\mathrm{T} \\
\text { Silent } \\
\text { p.Phe839Phe }\end{array}$ \\
\hline A. nancymaae & & $\begin{array}{l}\text { c. } 385 \mathrm{C}>\mathrm{T} \\
\text { Missense } \\
\text { p.His129Phe }\end{array}$ & & & & $\begin{array}{l}\text { c. } 1860 \mathrm{G}>\mathrm{A} \\
\text { Silent } \\
\text { p.Thr620Thr }\end{array}$ & & & $\begin{array}{l}\text { c.2517C }>\text { T } \\
\text { Silent } \\
\text { p.Phe839Phe }\end{array}$ \\
\hline S. robustus & & $\begin{array}{l}\text { c. } 385 \mathrm{C}>\mathrm{T} \\
\text { Missense } \\
\text { p.His129Phe }\end{array}$ & & & $\begin{array}{l}\text { c.1215C }>\mathrm{T} \\
\text { Silent } \\
\text { p.Asn405Asn }\end{array}$ & $\begin{array}{l}\text { c. } 1860 \mathrm{G}>\mathrm{A} \\
\text { Silent } \\
\text { p.Thr620Thr }\end{array}$ & & & $\begin{array}{l}\text { c.2517C }>\text { T } \\
\text { Silent } \\
\text { p.Phe839Phe }\end{array}$ \\
\hline C. capucinus & & $\begin{array}{l}\text { c. } 385 \mathrm{C}>\mathrm{T} \\
\text { Missense } \\
\text { p.His129Phe }\end{array}$ & & & $\begin{array}{l}\text { c. } 1215 \mathrm{C}>\mathrm{T} \\
\text { Silent } \\
\text { p.Asn405Asn }\end{array}$ & $\begin{array}{l}\text { c.1860G }>\text { A } \\
\text { Silent } \\
\text { p.Thr620Thr }\end{array}$ & & & $\begin{array}{l}\text { c.2517C }>\text { T } \\
\text { Silent } \\
\text { p.Phe839Phe }\end{array}$ \\
\hline S. boliviensis & & $\begin{array}{l}\text { c.385C }>\text { T } \\
\text { Missense } \\
\text { p.His129Phe }\end{array}$ & & & & $\begin{array}{l}\text { c.1860G }>\text { A } \\
\text { Silent } \\
\text { p.Thr620Thr }\end{array}$ & & & $\begin{array}{l}\text { c.2517C>T } \\
\text { Silent } \\
\text { p.Phe839Phe }\end{array}$ \\
\hline C. jacchus & $\begin{array}{l}\text { c.291A }>\mathrm{G} \\
\text { Silent } \\
\text { p.Glu97Glu }\end{array}$ & $\begin{array}{l}\text { c. } 385 \mathrm{C}>\mathrm{T} \\
\text { Missense } \\
\text { p.His129Phe }\end{array}$ & & $\begin{array}{l}\text { c.1140C }>\mathrm{T} \\
\text { Silent } \\
\text { p.Asn380Asn }\end{array}$ & & $\begin{array}{l}\text { c.1860G }>\text { A } \\
\text { Silent } \\
\text { p.Thr620Thr }\end{array}$ & & & $\begin{array}{l}\text { c. } 2517 \mathrm{C}>\mathrm{T} \\
\text { Silent } \\
\text { p.Phe839Phe }\end{array}$ \\
\hline C. goeldii & $\begin{array}{l}\text { c.291A }>\mathrm{G} \\
\text { Silent } \\
\text { p.Glu97Glu }\end{array}$ & $\begin{array}{l}\text { c.385C }>\text { T } \\
\text { Missense } \\
\text { p.His129Phe }\end{array}$ & & & & $\begin{array}{l}\text { c. } 1860 \mathrm{G}>\mathrm{A} \\
\text { Silent } \\
\text { p.Thr620Thr }\end{array}$ & & & $\begin{array}{l}\text { c.2517C }>\text { T } \\
\text { Silent } \\
\text { p.Phe839Phe }\end{array}$ \\
\hline O. garnettii & & $\begin{array}{l}\text { c.385C }>\mathrm{T} \\
\text { Missense } \\
\text { p.His129Tyr }\end{array}$ & & $\begin{array}{l}\text { c.1140C }>T \\
\text { Silent } \\
\text { p.Asn380Asn }\end{array}$ & $\begin{array}{l}\text { c. } 1215 \mathrm{C}>\mathrm{T} \\
\text { Silent } \\
\text { p.Asn } 405 \text { Asn }\end{array}$ & $\begin{array}{l}\text { c.1860G }>\text { A } \\
\text { Silent } \\
\text { p.Thr620Thr }\end{array}$ & & & $\begin{array}{l}\text { c.2517C }>\mathrm{T} \\
\text { Silent } \\
\text { p.Phe839Phe }\end{array}$ \\
\hline M. murinus & & $\begin{array}{l}\text { c.385C }>\mathrm{T} \\
\text { Missense } \\
\text { p.His129Tyr }\end{array}$ & & $\begin{array}{l}\text { c.1140C }>\mathrm{T} \\
\text { Silent } \\
\text { p.Asn380Asn }\end{array}$ & $\begin{array}{l}\text { c. } 1215 \mathrm{C}>\mathrm{T} \\
\text { Silent } \\
\text { p.Asn405Asn }\end{array}$ & $\begin{array}{l}\text { c.1860G }>\text { A } \\
\text { Silent } \\
\text { p.Thr620Thr }\end{array}$ & $\begin{array}{l}\left({ }^{*}\right) \\
\text { c.1943C>A } \\
\text { Missense } \\
\end{array}$ & $\begin{array}{l}\text { c. } 2463 \mathrm{~A}>\mathrm{G} \\
\text { Silent } \\
\text { p.Thr821Thr }\end{array}$ & $\begin{array}{l}\text { c. } 2517 \mathrm{C}>\mathrm{T} \\
\text { Silent } \\
\text { p.Phe } 839 \text { Phe }\end{array}$ \\
\hline
\end{tabular}

${ }^{*}{ }^{*}$ in Nomascus leucogenys, p.Asn380Thr results from c.1139A $>$ C changing AAC to ACC. $\left.{ }^{(* *}\right)$ in Microcebus murinus, c.1943C $>$ A does not produce a stop codon because it affects a different triplet.

not result in aminoacid substitutions in pBR? Nucleotide substitutions, mainly at third codon positions, may produce synonymous codons that specify the same aminoacids consequently to the redundancy of the genetic code. But despite the apparent invariability of the primary structure of the translated proteins, these synonymous mutations might not be innocuous. This implies a difference between "samesense" / "synonymous" (connoting identical aminoacid specificity) and "silent" (connoting lack of biological significance). Interestingly, the different frequencies with which redundant codons were used by the species studied herein, accounted for obvious disparities in codon usage for the $R B 1$ gene. Moreover, very similar codon usage biases were found to be shared by closely related species, accounting for evident phylogenetic signals. This finding suggested that natural selection must have optimized biological functions, like RNA translation by a preferential, combined usage of specific codons and transfer RNA (tRNA) molecules containing their corresponding anticodons. In this context, the replacement of a preferentially used codon by a rarely used, redundant codon might not be trivial. In $M D R 1$, a gene encoding a membrane bound transporter protein that actively effluxes a wide range of compounds from cells, the synonymous c. $3435 \mathrm{C}>\mathrm{T}$ polymorphism was found to affect protein expression in different organs with collateral effects at the mRNA level, protein 


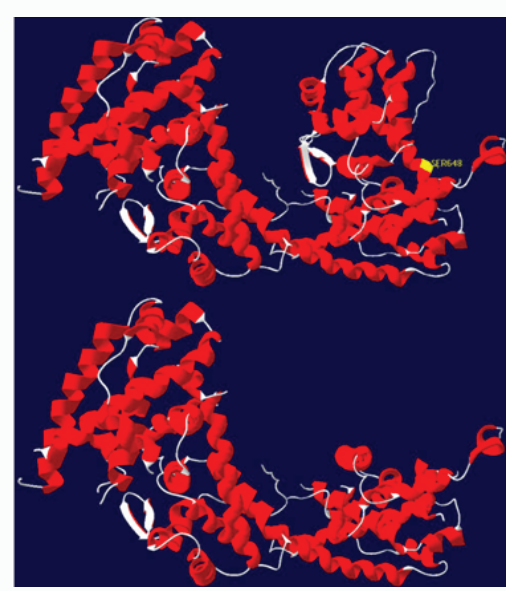

Figure 3: Top- Normal pRB configuration. The position of serine is highlighted in the protein. Bottom- Truncated pRB consequently to replacement of 648 serine codon by a stop codon.

folding, substrate specificity and drug pharmacokinetics [16]. This occurred because both $3435 \mathrm{C}$ and $3435 \mathrm{~T}$ alleles, though coding for the same aminoacid, produced dramatically different effects on the MDR1 protein. Regardless of these considerations, we cannot exclude that chance might be accountable for the observed association of several $R B 1$ mutations and retinoblastoma. To our knowledge, there is no population data on $R B 1$ in humans which could discriminate between neutral polymorphic traits and pathogenic mutations. The fact that some mutations associated to retinoblastoma are present in several non-human primates coexisting with presumably unaffected phenotypes, pointed to their ancient origin and may question their pathogenicity in humans. On the other hand, each species possesses a unique genome despite sharing different degrees of similarity with any other, a reason why the effect of an alteration in one species might not be directly equivalent to an alteration in another. The c.1943C $>$ A mutation that originated a stop codon (p.Ser648X) in humans differed from the alteration in the mouse lemur, resulting in replacement of serine by histidine (p.Ser648His). In this species, a frameshift mutation occurred due to a single nucleotide deletion that shifted the reading frame of six codons whose triplets ended up specifying for different aminoacids respective to the human and the ancestral primate sequence (Figure 4).

\section{A Historical Reconstruction Shows How Mutations Molded $R B_{1}$}

Comparative analyses of molecular data have been useful for tracing change along the evolution of $R B 1$. These allowed to identifying (i) the polarity of events responsible for the emergence of mutations, (ii) the physico-chemical effects conferred by aminoacid substitutions and (iii) codons and evolutionary lineages under selection. Once homologous genes are initially aligned, we may subsequently use different algorithms for building topologies or gene trees. These trees illustrate how related our homologous genes might be related and provide a clue to the direction (polarity) of events that might have occurred between them. Trees can be calibrated by including data from the fossil record for estimating the temporality of evolutionary events. Moreover, other algorithms can be used for identifying molecular alterations and selection in codons along the branches of an evolutionary tree(TreeSaap - http://dna.cs.byu.edu/treesaap) [17]. A detailed account on the evolution of $R B 1$ has been reported by Viana et al [12]. The RB1 gene tree shows how its exonic regions

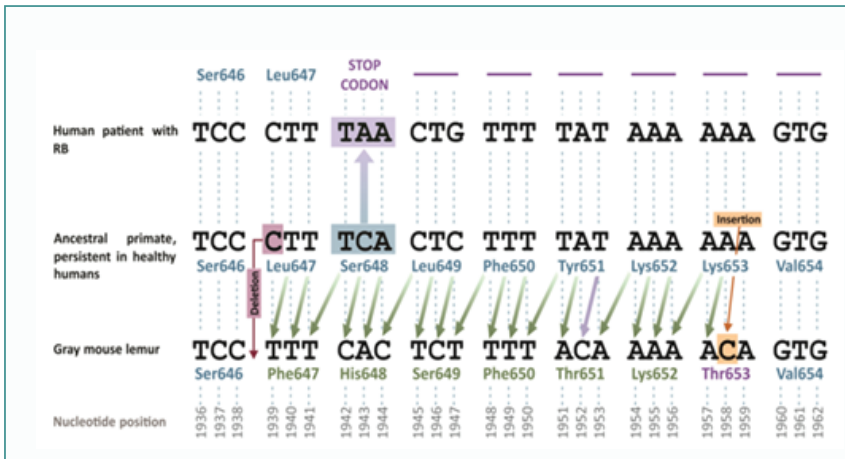

Figure 4: The c.1943C>A mutation at the second position of codon 648 resulted in a stop codon (TAA) and a truncated protein in humans with retinoblastoma. Although position 1943 in the gray mouse lemur shows A respective to $C$ in the ancestral primate and the normal human sequence, a single $\mathrm{C}>\mathrm{A}$ mutation has not occurred. This difference resulted from a deletion of $C$ at position 1939 in the lemur that shifted the reading frame of codons 647 to 652 and altered their triplets. An insertion of $C$ at position 1958 reinstated the original reading frame by creating ACA, a codon specifying for threonine. Note that an additional $T>C$ mutation occurred accounting for $C$ at position 1952 in the gray mouse lemur.

have evolved. The tree shows nodes from which branches emerge at different points; the end point of each branch representing the RB1 sequence found in each extant species. Along branches, codons where missense mutations resulted in substitutions of aminoacids with radical changes in physico-chemical properties are represented by circles. Some codons (in red) were additionally found to have been subjected to positive selection as well as the branch leading to the mouse lemur. The gene tree is calibrated to show a timescale that allows us to estimate the rate of change per branch. Differences in the amount of circles between branches during any given time indicate that the rate of evolutionary events differed between evolutionary lineages (Figure 5). This provides us with a dynamic scenario, suggesting that this gene tree may not represent the end of the $R B 1$ story because all genes, including ours, are continuously evolving.

\section{Disease-related $R B \boldsymbol{1}$ Mutations Re-analyzed}

Re-analysis of the mutations listed in Table 1 showed some interesting findings. The polarity (direction) of mutational events indicated that some codons were ancestral with respect to others that were considered to be derived. From these ancestral codons, we were able to trace how they changed along lineages and nodes from which tree branches emerged. We were then capable of understanding how two

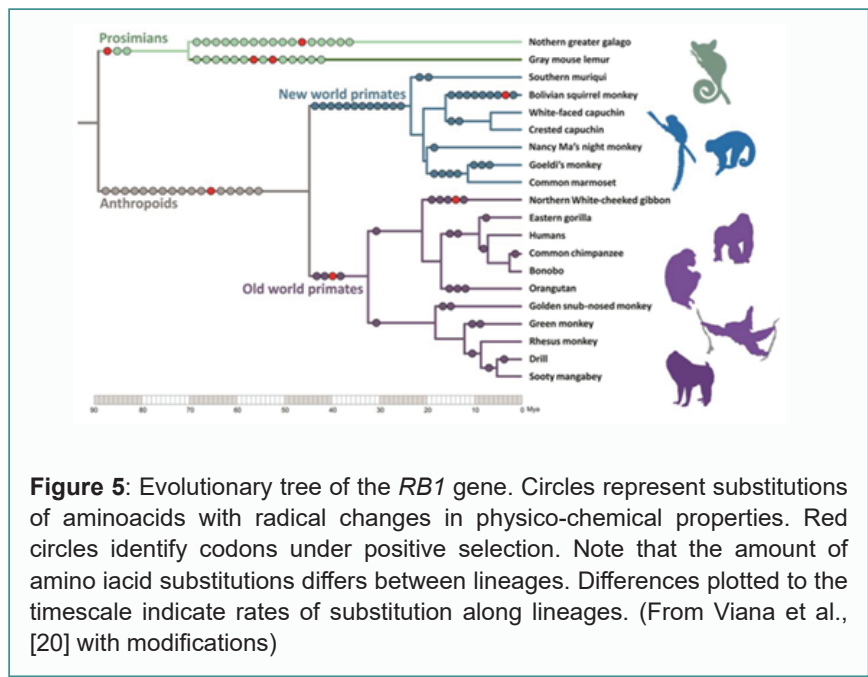




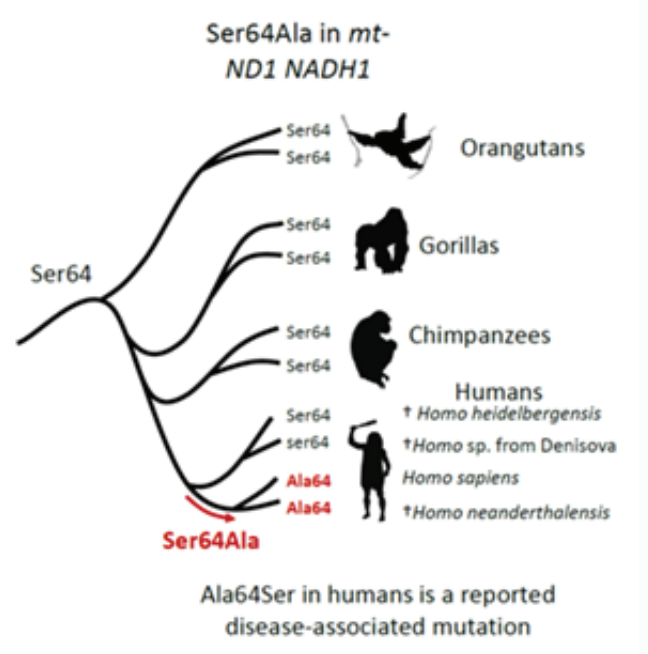

Figure 6: Phylogenic tree of mtND1 showing that codon 64 coded for serine in the common ancestral hominid and all descendant hominid species except for Homo sapiens and Homo neanderthalensis in which a missense mutation (p.Ser64Ala) replaced serine by alanine. The m.3496G>T;p. Ala64Ser in Japanese families with LHON is an evolutionary reversion to an ancestral trait (from Tavares and Seuánez 2017 [19]).

mutations (indicated by asterisks in Table 1)might have emerged and ended up being different from those found in humans. Moreover, we were surprised to find that in five of the nine mutations associated with retinoblastoma in humans, one missense (c.385C $>$ T;p.His129Tyr) and four same-sense mutations(c.1140C $>$ T; p.Asn380Asn, c.1215C $>$ T;p. Asn405Asn, c.1860G >A; p.Thr620Thr, and c.2517C > T;p.Phe839Phe) represented evolutionary reversions to ancestral primate codons. Additionally, the mutations in codons 405 and 620 were found to be under negative selection. When looking at other disease associated mutations in other genes within an evolutionary perspective, we were surprised to a find an evolutionary regression in a disease associated mutation affecting the mitochondrial gene mtND1 (mitochondrially encoded NADH:ubiquinone oxidoreductase core subunit 1).This was the case of a missense mutation (m.3496G > T;p.Ala64Ser), found to be associated with Leber's hereditary optic neuropathy (LHON) in Japanese families [18]. A phylogenic analysis of mtND1 showed that codon 64 was highly variables along primate evolution, but more recently coded for serine in the common ancestral hominid and all descendant hominid species except for Homo sapiens and Homo neanderthalensis, in which a missense mutation (p.Ser64Ala) replaced serine withal nine (Figure 6). This information allowed us to interpret m.3496G > T;p.Ala64Ser in Japanese families with LHON as an evolutionary reversion to an ancestral trait [19].

\section{Conclusion: Evolution Contributes to} Understanding Disease in Humans and Lack of Pathogenicity in Non-Human Primates

The historic events along $R B 1$ evolution provide new insights to understand this paradox. The presumably atavistic $R B 1$ mutations and their association with disease phenotypes is a matter of interest given that disease-related evolutionary regressions can also occur in other genes. Similarly, as in the case of same-sense RB1 mutations, it is probable that they have disrupted ancient adaptations that took place in our evolutionary lineage involving concomitant changes in other genes. This may be why we are now longer allowed us to "revert" to ancestral states without being adversely affected. Regressions are thus, selectively unfavorable changes because they alter biological functions that have been perfected during evolution.

\section{Acknowledgements}

Work supported by Conselho Nacional de Desenvolvimento (Brazil), grant 303306/2010-6 and Fundação Carlos Chagas Filho de Amparo à Pesquisa do Estado do Rio de Janeiro (BR) and Coordenação de Aperfeiçoamento de Pessoal de Nível Superior Award Number: $209101 /$ E-44/2014.

\section{References}

1. Abramson DH. Retinoblastoma in the 20th Century: Past Success and Future Challenges The Weisenfeld Lecture. Invest Ophthalmol Vis Sci [Internet]. 2005;46(8):2684-91.

2. Dimaras H, Corson TW, Cobrinik D, White A, Zhao J, Munier FL, et al. Retinoblastoma. Nat Rev Dis Prim [Internet]. 2015;1:15021.

3. Friend SH, Bernards R, Rogelj S, Weinberg RA, Rapaport JM, Albert DM, et al. A human DNA segment with properties of the gene that predisposes to retinoblastoma and osteosarcoma. Nature [Internet]. 1986;323(6089):643-6.

4. Hanahan D, Weinberg RA. Review Hallmarks of Cancer : The Next Generation. Cell [Internet]. 2011;144(5):646-74.

5. Chinnam M, Goodrich DW. RB1, development, and cancer. Curr Top Dev Biol. 2011;94:129-69.

6. Hong FD, Huang HJ, To H, Young LJ, Oro A, Bookstein R, et al. Structure of the human retinoblastoma gene. Proc Natl Acad Sci U S A. 1989;86(14):5502-6.

7. Knudson AGJ. Mutation and cancer: statistical study of retinoblastoma. Proc Natl Acad Sci U S A. 1971;68(4):820-3.

8. Toguchida J, McGee TL, Paterson JC, Eagle JR, Tucker S, Yandell DW, et al. Complete genomic sequence of the human retinoblastoma susceptibility gene. Genomics. 1993;17(3):535-43.

9. Verma RS, Ramesh KH, Samonte R V, Conte RA. Mapping the homolog of the human Rb1 gene to chromosome 14 of higher primates. Mamm Genome. 1996;7(8):591-2.

10. Xiao B, Spencer J, Clements A, Ali-Khan N, Mittnacht S, Broceño C, et al. Crystal structure of the retinoblastoma tumor suppressor protein bound to E2F and the molecular basis of its regulation. Proc Natl Acad Sci U S A. 2003;100(5):2363-8.

11. Adams PD, Li X, Sellers WR, Baker KB, Leng X, Harper JW, et al. Retinoblastoma Protein Contains a C-terminal Motif That Targets It for Phosphorylation by Cyclincdk Complexes. 1999;19(2):1068-80.

12. Viana MC, Tavares WC, Brant AC, Boroni M, Seuanez HN. The human retinoblastoma susceptibility gene (RB1): an evolutionary story in primates. Mamm Genome. 2017;28(5-6):198-212.

13. Fokkema IFAC, Taschner PEM, Schaafsma GCP, Celli J, Laros JFJ, den Dunnen JT. LOVD v.2.0: the next generation in gene variant databases. Hum Mutat. 2011;32(5):557-63.

14. Guex N, Peitsch MC. SWISS-MODEL and the Swiss-PdbViewer: An environment for comparative protein modeling. Electrophoresis. 1997;18(15): 2714-23.

15. Kopanos C, Tsiolkas V, Kouris A, Chapple CE, Albarca Aguilera M, Meyer R, et al. VarSome: the human genomic variant search engine. Bioinformatics [Internet]. 2018;35(11):1978-80.

16. Fung KL, Gottesman MM. A synonymous polymorphism in a common MDR1 (ABCB1) haplotype shapes protein function. Biochim Biophys Acta [Internet]. 2009;1794(5):860-71.

17. Ison J, Rapacki K, Ménager H, Kalaš M, Rydza E, Chmura P, et al. Tools and data services registry: a community effort to document bioinformatics resources. Nucleic Acids Res [Internet]. 2015;44(D1):D38-47.

18. Matsumoto M, Hayasaka S, Kadoi C, Hotta Y, Fujiki K, Fujimaki T, et al. Secondary mutations of mitochondrial DNA in Japanese patients with Leber's hereditary optic 
neuropathy. Ophthalmic Genet. 1999;20(3):153-60.

19. Tavares WC, Seuanez HN. Disease-associated mitochondrial mutations and the evolution of primate mitogenomes. PLoS One. 2017;12(5):e0177403.

20. Stelzer G, Rosen N, Plaschkes I, Zimmerman S, Twik M, Fishilevich S, et al. The GeneCards Suite: From Gene Data Mining to Disease Genome Sequence Analyses. Curr Protoc Bioinforma. 2016;54:1.30.1-1.30.33.

21. The UniProt Consortium. UniProt: a hub for protein information. Nucleic Acids Res. 2015;43(D1):D204-12.

22. Finn RD, Coggill P, Eberhardt RY, Eddy SR, Mistry J, Mitchell AL, et al. The Pfam protein families database : towards a more sustainable future. 2016;:279-85.

23. Hasan MM, Brocca S, Sacco E, Spinelli M, Papaleo E, Lambrughi M, et al. A comparative study of Whi5 and retinoblastoma proteins: from sequence and structure analysis to intracellular networks. Front Physiol. 2013;4:315.

24. Rubin SM, Gall A-L, Zheng N, Pavletich NP. Structure of the Rb C-terminal domain bound to E2F1-DP1: a mechanism for phosphorylation-induced E2F release. Cell. 2005;123(6):1093-106. 